ISSN : 2622-6154 (print)

\title{
ANALISIS PERMINTAAN TELUR AYAM DI KABUPATEN MAGETAN
}

Nia Fridayanti ${ }^{1}$, Sri Marwanti ${ }^{2}$, Ernoiz Antriyandarti ${ }^{3}$

\author{
${ }^{1}$ Program Studi Agribisnis, Fakultas Pertanian, Universitas Sebelas Maret \\ ${ }^{2}$ Program Studi Agribisnis, Fakultas Pertanian, Universitas Sebelas Maret \\ ${ }^{3}$ Program Studi Agribisnis, Fakultas Pertanian, Universitas Sebelas Maret
}

email korespondensi: fridayantinia22@gmail.com

\begin{abstract}
This research aims to identify and to analyze the variables which influenced the chicken egg demand in Magetan District and to know its elasticity. This research used descriptive and analytical method. The research location was chosen purposively in Magetan. By using 27 years time series data, this study applied Cobb Douglass demand function with Ordinary Least Squre method. The analysis result shows that the chicken egg demand function model in Magetan District has $\mathrm{R}$ square value 0,940, it means that $94 \%$ demand of chicken egg. The remaining $6 \%$ is explained by other variables outside the models. Based on the analysis of $F$ test, it can be seen that the significance of 0,000 , which means that the observed independent variables, significantly affect the demand for chicken eggs in Magetan District. The results showed that the price of chicken egg, chicken meat, rice, also population and income per capita have significant effect on chicken egg demand in Magetan District. Race egg price is inelastic since its value is less than one $(-0,280)$. Chicken meat price has subtitute elasticity since its value is positive $(0,911)$. Rice price has complementary elasticity, since its value is negative $(0,233)$. Income elasticity has a negative $(-$ $0,476)$ value, means that egg is an inferior good.
\end{abstract}

Keyword: Demand Elasticity, Demand of Chicken Egg

\section{INTISARI}

Tujuan penelitian ini adalah untuk mengidentifikasi dan menganalisis variabel-variabel yang mempengaruhi permintaan telur ayam, serta mengetahui elastisitas permintaan telur ayam di Kabupaten Magetan. Metode dasar yang digunakan adalah metode deskriptif dan analitis. Lokasi penelitian dipilih secara sengaja di Kabupaten Magetan. Data yang digunakan adalah data time series selama 27 tahun. Metode analisis data yang digunakan fungsi perminaan Cobb Douglass dengan metode Ordinary Least Square. Model fungsi permintaan telur ayam di Kabupaten Magetan memiliki nilai R square sebesar 0,940 berarti $94 \%$ permintaan telur ayam dapat dijelaskan oleh variabel bebas. Sisanya sebesar $6 \%$ dijelaskan oleh variabel lain di luar model. Berdasarkan analisis uji $\mathrm{F}$ yang dilakukan dapat diketahui bahwa signifikansi sebesar 0,000 berarti variabel-variabel bebas yang diamati secara bersama-sama berpengaruh nyata terhadap permintaan telur ayam di Kabupaten Magetan. Hasil analisis menunjukkan bahwa harga telur ayam ras, harga daging ayam, harga beras, jumlah penduduk dan pendapatan perkapita berpengaruh terhadap permintaan telur ayam di Kabupaten Magetan. Elastisitas harga telur ayam ras bernilai negatif $(-0,280)$ dan bersifat inelasitis. Elastisitas silang pada harga daging ayam bernilai positif $(0,911)$ berarti daging ayam merupakan barang subtitusi (pengganti) dari telur ayam. Elastisitas silang harga beras bernilai negatif kurang dari satu $(-0,233)$, berarti beras merupakan barang komplementer (pendamping) dari telur ayam. Elastisitas pendapatan bernilai negatif $(-0,476)$ berarti telur ayam ras merupakan barang inferior.

Kata Kunci: Elastisitas Permintaan, Permintaan Telur Ayam. 


\section{PENDAHULUAN}

Telur merupakan bahan pangan hasil ternak unggas yang memiliki sumber protein hewani, mempunyai rasa yang lezat, mudah dicerna dan bergizi tinggi (Susanto, et al. 2015). Protein yang terkandung di dalam telur sangat berperan dalam tubuh manusia karena protein berfungsi sebagai zat pembangun.Pengeluaran untuk konsumsi pangan dan gizi penduduk Indonesia masih lebih besar dari pengeluaran untuk konsumsi bukan pangan (Marwanti, 2002).

Jumlah penduduk di Kabupaten Magetan mengalami fluktuasi. Tahun 2010 sampai dengan tahun 2014 jumlah penduduk mengalami kenaikan. Namun, tahun 2015 jumlah penduduk di Kabupaten Magetan mengalami penurunan. Hal ini dikarenakan jumlah kelahiran dan kedatangan sebesar 9.068 jiwa lebih kecil dibandingkan dengan kematian dan perpindahan sebesar 9.381 jiwa. Tahun 2016 jumlah penduduk mengalami kenaikan. Total jumlah penduduk tahun 2016 mencapai 684.053 jiwa dengan kenaikan laju pertumbuhan penduduk sebesar 0,96\% (BPS Kabupaten Magetan, 2017).

Jumlah penduduk yang berfluktuasi akan mempengaruhi permintaan penduduk terhadap telur ayam. Permintaan adalah banyaknya jumlah barang yang diminta pada suatu pasar tertentu dengan tingkat harga tertentu pada tingkat pendapatan tertentu dalam periode tertentu. Terdapat beberapa faktor yang dapat mempengaruhi permintaan dari seorang individu atau masyarakat terhadap suatu barang, diantaranya harga barang itu sendiri, tingkat pendapatan, jumlah penduduk, harga barang lain dan selera (Putong, 2003).

Antriyandarti (2012) menyatakan permintaan akan telur ayam sangat erat kaitannya dengan harga karena masyarakat memiliki kendala pendapatan dalam memenuhi kebutuhannya. Meningkatnya pendapatan sangat berpengaruh terhadap permintaan telur ayam. Apabila pendapatan berubah maka jumlah permintaan akan telur ayampun akan berubah sehingga dapat mempengaruhi kegiatan produksi dan perdagangan telur ayam. Pendapatan merupakan nilai maksimum yang dapat dikonsumsi oleh seseorang dalam suatu periode dengan mengharapkan keadaan yang sama pada akhir periode seperti keadaan semula (Sutisna, 2001). Pendapatan di Kabupaten Magetan itu sendiri cenderung mengalami kenaikan dari tahun ke tahun. Bertambahnya jumlah penduduk, meningkatnya pendapatan perkapita penduduk dan juga perubahan harga telur ayam ras akan mempengaruhi permintaan telur ayam perkapita di Kabupaten Magetan.

Tujuan dari penelitian ini yaitu (1) mengidentifikasi dan menganalisis variabelvariabel apa saja yang mempengaruhi permintaan telur ayam di Kabupaten Magetan, serta (2) mengetahui elastisitas permintaan telur ayam di Kabupaten Magetan. 


\section{METODE PENELITIAN}

\section{Metode Dasar Penelitian}

Metode dasar yang digunakan dalam penelitian adalah metode deskriptif dan analitis. Sumodiningrat (2007) menyatakan secara harfiah metode deskriptif adalah metode untuk menggambarkan situasi atau kejadian. Metode analitis merupakan sebuah proses umum penggabungan kekuatan metode ilmiah dengan menggunakan proses formal untuk menyelesaikan proses dan berbagai permasalahan.

\section{Metode Penentuan Lokasi}

Lokasi penelitian diambil secara purposive yaitu pengambilan sampel secara sengaja yaitu di Kabupaten Magetan. Endraswara (2006) menyatakan sample purposive merupakanpenyampelan yang dilakukan dengan menyesuaikan gagasan, asumsi, sasaran, tujuan, manfaat yang hendak dicapai peneliti.Cara pengambilan sampel dengan sengaja berdasarkan pertimbangan-pertimbangan tertentu penelitian.

\section{Jenis dan Sumber Data}

Data yang digunakan adalah data sekunder berupa time series mulai tahun 19902016. Data tersebut meliputi data permintaan telur ayam ras, data harga telur ayam, harga daging ayam, harga beras, jumlah pendudukdan pendapatan per kapita. Data diperoleh dari Badan Pusat Statistik, Dinas Tanaman Pangan, Holtikultura, Perkebunan dan Ketahanan Pangan Kabupaten Magetan serta instansi - instansi lain yang terkait.

\section{Metode Analisis Data}

\section{Estimasi Fungsi Permintaan}

Supranto (2001) menyatakan fungsi permintaan telur ayam di Kabupaten Magetan dianalisis menggunakan regresi berganda yang diestimasi melalui logaritma natural model Cobb-Douglas. Secara matematis fungsi permintaan telur ayam dirumuskan sebagai berikut :

$$
\text { Ln } \mathrm{Y}=\mathrm{Ln} b 0+\mathrm{b} 1 \operatorname{Ln} \mathrm{X} 1+\mathrm{b} 2 \operatorname{Ln} \mathrm{X} 2+\mathrm{b} 3 \operatorname{Ln} \mathrm{X} 3+\mathrm{b} 4 \operatorname{Ln} \mathrm{X} 4+\mathrm{b} 5 \operatorname{Ln} \mathrm{X} 5+\mathrm{e}
$$

Keterangan:

LnY adalah permintaan telur ayam ras (kg/tahun), Lnb0 adalah konstanta, b1,b2,b3,...b5 adalah koefisien regesi, $\mathrm{LnX} 1$ adalah harga telur ayam ras $(\mathrm{Rp} / \mathrm{kg})$, LnX2 adalah harga daging ayam (Rp/kg), LnX3 adalah harga beras (Rp/kg), LnX4 adalah jumlah penduduk (jiwa/tahun) dan LnX5 adalah pendapatan perkapita (Rp/tahun).

\section{A. Pengujian Model}

\section{1) Uji Koefisien Determinasi (R2)}

Nilai koefisien determinasi R2 dapat dipakai untuk memprediksi seberapa besar kontribusi pengaruh variabel bebas (X) terhadap variabel terikat (Y) dengan syarat hasil uji $\mathrm{F}$ dalam analisis regresi bernilai signifikan. 


\section{2) Uji F}

Gujarati (2003) menyatakan untuk menguji seluruh variabel bebas yang diteliti berpengaruh secara bersama-sama terhadap variabel tak bebas dilakukan uji F.

3) $\mathbf{U j i}-\mathbf{t}$

Gujarati (2003) menyatakan untuk mengetahui apakah variabel yang digunakan secara parsial atau individu berpengaruh nyata terhadap variabel tak bebas.

\section{B. Pengujian Asumsi Klasik}

\section{1) Multikolinearitas}

Prinyastanto (2015) menyatakanmultikolinearitas merupakan uji yang bertujuan untuk melihat apakah variabel-variabel bebas dalam persamaan regeresi linier berganda mempunyai korelasi yang erat satu sama lainnya. Cara yang digunakan untuk mendeteksi ada tidaknya multikolinearitas yaitu dengan berdasarkan pada nilai tolerance dan VIF (Variance Inflation Factors). Rule of thumb untuk menentukan bahwa nilai tolerance tidak berbahaya terhadap gejala multikolinearitas adalah 0,10 . Rule of thumb yang digunakan untuk menentukan bahwa nilai VIF tidak berbahaya adalah kurang dari 10.

\section{2) Heterokedastisitas}

Santoso (2002) menyatakan uji heterokedastisitas bertujuan untuk menguji apakah dalam model regresi terjadi ketidaksamaan variance dari satu pengamatan ke pengamatan yang lain dilihat dari diagram pencar scatterplot.

\section{3) Autokorelasi}

Autokorelasi adalah suatu keadaan adanya korelasi antara kesalahan pengganggu periode tertentu (t) dengan kesalahan pengganggu pada periode sebelumnya (t-1).Santoso (2002) menyatakan untuk mendeteksi adanya autokorelasi adalah dengan panduan angka D-W (DurbinWatson), dengan patokan : (a) Angka D-W dibawah angka -2 berarti terdapat autokorelasi positif, (b) Angka D-W diantara -2 sampai +2 berarti tidak terdapat autokorelasi, (c) Angka D-W diatas angka +2 berarti terdapat autokorelasi negatif.

\section{Elastisitas Permintaan}

Elastisitas permintaan diketahui dari nilai koefisien regresi masing-masing variabel penduganya. Elastisitas permintaan mengukur perubahan relatif dalam jumlah unit barang yang dibeli sebagai akibat adanya perubahan salah satu variabel yang mempengaruhinya. Elastisitas permintaan dibagi menjadi tiga, yaitu :

\section{a) Elastisitas harga (Price Elasticity of Demand).}

Firdaus (2008) menyatakan kriteria dari elastisitas harga yaitu :Ep $<1$ berarti inelastis; Ep > 1berartielastis; Ep $=1$ berartielastis uniter; Ep $=0$ berartiinelastis sempurna; Ep = berartielastis sempurna. 
ISSN : 2622-6154 (print)

\section{b) Elastisitas silang (Cross Elasticity)}

Firdaus (2008) menyatakan kriteria dari elastis silang yaitu :Ec $>0$ berarti barang substitusi; Ec $<0$ berarti barang komplementer; Ec $=0$ berarti dua macam barang tersebut tidak berkaitan.

c) Elastisitas pendapatan (Income Elasticity)

Sudiyono (2002) menyatakan kriteria dari elastisitas pendapatan yaitu :Ei > Oberarti barang normal; Ei $=0$ berarti barang netral; Ei $<0$ berarti barang inferior.

\section{HASIL DAN PEMBAHASAN}

Hasil analisis data dengan SPSS metode enter maka diperoleh model regresi fungsi permintaan telur ayam di Kabupaten Magetan ditampilkan pada tabel hasil analisis permintaan telur ayam di Kabupaten Magetan tahun 1990-2016. Tabel analisis permintaan telur ayam di Kabupaten Magetan tahun 1990-2016 dapat dilihat pada Tabel 1 .

Tabel 1. Hasil Analisis Permintaan Telur Ayam di Kabupaten Magetan Tahun 1990-2016.

\begin{tabular}{llrc}
\hline \multicolumn{1}{c}{ Variabel } & \multicolumn{1}{c}{ Koefisien } & \multicolumn{1}{c}{$\begin{array}{c}\text { Standart } \\
\text { Error }\end{array}$} & Sig \\
\hline Constant & $-131,348^{* * *}$ & 38,567 & 0,003 \\
Harga Telur Ayam Ras $\left(\mathrm{X}_{1}\right)$ & $-0,280^{* *}$ & 0,129 & 0,042 \\
Harga Daging Ayam $\left(\mathrm{X}_{2}\right)$ & $0,911^{* * *}$ & 0,137 & 0,000 \\
Harga Beras $\left(\mathrm{X}_{3}\right)$ & $-0,233^{* *}$ & 0,086 & 0,013 \\
Jumlah Penduduk $\left(\mathrm{X}_{4}\right)$ & $11,146^{* * *}$ & 2,742 & 0,001 \\
Pendapatan Perkapita $\left(\mathrm{X}_{5}\right)$ & $-0,476^{* * *}$ & 0,096 & 0,000 \\
$\mathrm{R}^{2}$ & 0,940 & & \\
F hitung & $65,451^{* * *}$ & & 0,000 \\
Nilai DW & 1,694 & & \\
Jumlah Observasi (N) & 27 & & \\
\hline Sumber: Anasis Data Sekung
\end{tabular}

Sumber: Analisis Data Sekunder, 2018

Keterangan :

*** berarti signifikansi $<0,01$, pada tingkat kepercayaan 99\%; ** berarti signifikansi $<0,05$, pada tingkat kepercayaan 95\%; ns berarti tidak signifikansi.

\section{Estimasi Fungsi Permintaan}

Model regresi fungsi permintaan telur ayam di Kabupaten Magetan adalah sebagai berikut: $\operatorname{LnY}=-131,348-0,280 \operatorname{LnX} 1+0,911 \operatorname{LnX} 2-0,2373 \operatorname{LnX} 3+11,146 \operatorname{LnX} 4-$

\section{$0,476 \operatorname{LnX} 5$}

\section{A. Pengujian Model}

\section{1) Koefisien Determintasi (R2)}

Berdasarkan Tabel 1. nilai R Square yang diperoleh sebesar 0,940 yang berarti sebesar $94 \%$ permintaan telur ayam di Kabupaten Magetan dapat dijelaskan oleh variabel bebas yang digunakan dalam model yaitu harga telur ayam ras, harga daging ayam, harga beras, jumlah penduduk, dan pendapatan 
perkapita. Sisanya sebesar $6 \%$ dijelaskan oleh variabel lain di luar model, misalnya: selera, status sosial, harga barang lainnya diluar variabel yang sudah ditetapkan, preferensi konsumen dan lain sebagainya.

2) $\mathbf{U j i} \mathbf{F}$

Berdasarkan analisis uji F pada Tabel 1. yang dilakukan dapat diketahui signifikansi sebesar $0,000<\square=0,05$. Hal ini menunjukkan bahwa variabelvariabel bebas yang diamati yaitu harga telur ayam ras, harga daging ayam, harga beras, jumlah penduduk, dan pendapatan perkapita secara bersama-sama berpengaruh nyata terhadap permintaan telur ayam di Kabupaten Magetan.

\section{3) Uji t}

Berdasarkan uji t pada Tabel 1. maka diperoleh hasil bahwa harga telur ayam ras, harga daging ayam, harga beras, jumlah penduduk dan pendapatan perkapita secara individu berpengaruh nyata terhadap permintaan telur ayam di Kabupaten Magetan. Variabel harga telur ayam ras menunjukkan signifikansi pada tingkat kepercayaan 95\% karena nilai sig $0,042<0,05$. Variabel harga daging ayam menunjukan signifikansi pada tingkat kepercayaan 99\% karena nilai sig $0,000<0,01$. Variabel harga beras menunjukkan pada tingkat kepercayaan $95 \%$ karena nilai sig $0,013<0,05$. Variabel jumlah penduduk menunjukan signifikansi pada tingkat kepercayaan 99\% karena nilai sig 0,001 $<0,01$. Variabel pendapatan perkapita menunjukan signifikansi pada tingkat kepercayaan 99\% karena nilai sig 0,000 <0,01.

\section{B. Pengujian Asumsi Klasik}

\section{1) Multikolinearitas}

Pengujian adanya multikolinearitas atau tidak dapat dilihat dari nilai VIF. Nilai VIF < 10 berarti antara variabel bebas tidak terjadi multikolinearitas dan sebaliknya. Hasil analisis uji multikolinearitas dapat dilihat pada Tabel 12 .

Tabel 2. Analsis Uji Multikolinearitas

\begin{tabular}{lcc}
\hline \multirow{2}{*}{ Model } & \multicolumn{2}{c}{ Collinearity Statistic } \\
\cline { 2 - 3 } & Tolerance & \multicolumn{1}{c}{ VIF } \\
\hline (Constant) & 0,545 & 1,835 \\
Harga Telur Ayam Ras $\left(\mathrm{X}_{1}\right)$ & 0,296 & 3,373 \\
Harga Daging Ayam $\left(\mathrm{X}_{2}\right)$ & 0,763 & 1,311 \\
Harga Beras $\left(\mathrm{X}_{3}\right)$ & 0,132 & 7,570 \\
Jumlah Penduduk $\left(\mathrm{X}_{4}\right)$ & 0,112 & 8,941 \\
Pendapatan Perkapita $\left(\mathrm{X}_{5}\right)$ & \multicolumn{2}{c}{}
\end{tabular}

Sumber: Analisis Data Sekunder, 2018

Hasil analisis uji multikolinearitas diperoleh nilai VIF $<10$ untuk semua variabel bebas yaitu harga telur ayam ras, harga daging ayam, harga beras, jumlah penduduk, dan pendapatan perkapita. Artinya tidak terjadi multikolinearitas di antara variabel-variabel bebas. 
ISSN : 2622-6154 (print)

\section{2) Heterokedastisitas}

Pada penelitian ini diketahui bahwa persamaan regresi tidak mengalami heterokedastisitas. Hal ini dapat dilihat dari grafik scatterplot yang titiktitiknya tidak membentuk pola tertentu

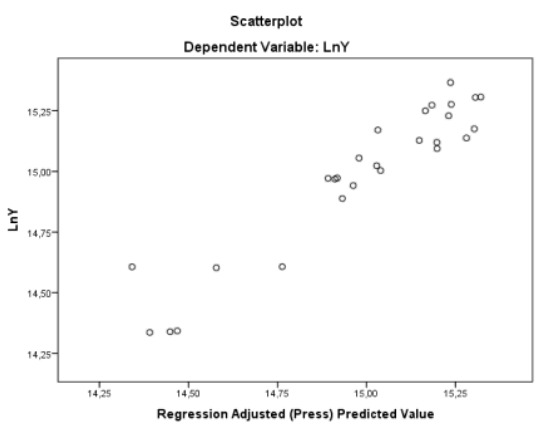

Grafik 1. Scatterplot dari Uji Heterokedastisitas

\section{3) Autokorelasi}

Berdasarkan hasil analisis permintaan telur ayam di Kabupaten Magetan tahun 1990-2016 maka diperoleh nilai Durbin Watson sebesar 1,694. Hasil tersebut menunjukkan bahwa tidak terjadi autokorelasi karena nilai DW diantara -2 dan +2 . Nilai tersebut dapat dilihat pada Tabel 1 .

\section{Elastisitas Permintaan Telur Ayam di Kabupaten Magetan}

Hasil analisis elastisitas permintaan telur ayam di Kabupaten Magetan dapat dilihat pada Tabel 3.

Tabel 3. Nilai Elastisitas Permintaan Telur Ayam di Kabupaten Magetan

\begin{tabular}{lrrr}
\hline \multirow{2}{*}{ Variabel } & \multicolumn{3}{c}{ Nilai Elastisitas Permintaan } \\
\cline { 2 - 4 } & Harga & Silang & Pendapatan \\
\hline Harga Telur Ayam Ras $\left(\mathrm{X}_{1)}\right.$ & $-0,280$ & - & - \\
Harga Daging Ayam $\left(\mathrm{X}_{2}\right)$ & - & 0,911 & - \\
Harga Beras $\left(\mathrm{X}_{3}\right)$ & - & $-0,233$ & - \\
Pendapatan Perkapita $\left(\mathrm{X}_{5}\right)$ & - & - & $-0,476$ \\
\hline
\end{tabular}

Sumber: Analsis Data Sekunder, 2018

\section{a) Elastisitas Harga}

Nilai koefisien elastisitas harga telur ayam ras sebesar -0,280 yang artinya setiap kenaikan $1 \%$ maka permintaan telur ayam akan menurun sebesar $0,280 \%$, begitu juga sebaliknya. Nilai koefisien elastisitas harga telur ayam ras diketahui kurang dari 1 . Hal tersebut menunjukkan bahwa harga telur ayam ras bersifat inelastis. Hal ini sesuai dengan pendapat Isman, et al (2011) yang menyatakan bahwa harga telur ayam ras bernilai negatif yang artinya bersifat inelasitis. Sehingga setiap kenaikan harga pada telur ayam ras maka permintaannya akan berkurang sesuai dengan hukum permintaan.

b) Elastisitas Silang

Nilai koefisien regresi harga daging ayam 0,911, artinya setiap kenaikan harga daging ayam sebesar $1 \%$ maka permintaan akan telur ayam naik sebesar $0,911 \%$, begitu juga sebaliknya. Berdasarkan penelitian ini maka diperoleh hasil 
ISSN : 2622-6154 (print)

bahwa daging ayam sebagai barang substitusi dari telur ayam karena nilai elastisitasnya lebih dari nol ( $\mathrm{Ec}>0)$. Hal ini sesuai dengan pendapat Fitrini, et al (2006) yang menyatakan bahwa daging ayam merupakan barang substitusi bagi telur ayam. Pada umumnya masyakarat Kabupaten Magetan menggunakan daging ayam sebagai lauk pauk. Jika harga daging ayam murah maka permintaan akan telur ayam berkurang karena penduduk Kabupaten Magetan menggantinya dengan daging ayam. Sebaliknya, jika daging harga daging ayam mahal maka permintaan telur ayam akan meningkat.

Elastisitas harga beras terhadap permintaan telur ayam adalah -0,233 artinya setiap kenaikan harga beras sebesar $1 \%$ maka permintaan telur ayam menurun sebesar 0,233\%. Beras merupakan barang komplementer karena nilai elastisitasnya kurang dari nol $(\mathrm{Ec}<0)$. Hal ini sesuai dengan penelitian Wahyuningsih (2008) yang menyatakan beras merupakan barang komplementer dari telur ayam. Penduduk Kabupaten Magetan pada umumnya menggunakan telur ayam sebagai pendamping dari nasi. Masakan tertentu seperti nasi goreng, beras dan telur ayam digunakan bersama-sama. Jika pendapatan tetap dan harga beras naik maka akan menyebabkan penurunan pada daya beli telur ayam karena mereka menggantinya dengan makanan yang lebih murah dan terjangkau dibandingkan dengan telur ayam. Oleh karena itu apabila terjadi kenaikan harga beras, maka permintaan telur ayam akan menurun karena beras merupakan barang pelengkap yang mempunyai hubungan negatif dengan telur ayam.

c) Elastisitas Pendapatan

Koefisien regresi dari pendapatan perkapita adalah -0,476 artinya setiap kenaikan pendapatan sebesar $1 \%$ maka terjadi penurunan permintaan telur ayam sebesar 0,476\% dan sebaliknya. Nilai elastisitas pendapatan bertanda negatif, ini berarti telur ayam merupakan barang inferior, jika pendapatan naik maka permintaan akan telur ayam menurun karena masyarakat mampu untuk membeli barang substitusi yang lebih tinggi harganya seperti ikan, daging ayam, daging sapi dan lain sebagainya. Telur ayam merupakan barang inferior karena bagi penduduk Kabupaten Magetan, telur ayam sudah dirasa sebagai makanan pokok yang selalu ada setiap hari. Hal ini sesuai dengan hasil penelitian dari Fitrini, et al (2006) yang menyatakan bahwa nilai koefisien pendapatan perkapita adalah negatif yang berarti inferior.

\section{KESIMPULAN}

Variabel yang mempengaruhi permintaan telur ayam di Kabupaten Magetan adalah harga telur ayam ras, harga daging ayam, harga beras, jumlah penduduk dan pendapatan perkapita. Hasil analisis elastisitas permintaan yaitu elastisitas harga telur ayam ras bernilai kurang dari 1 yaitu $-0,280$ artinya harga telur ayam bersifat inelastis yang berarti jika harga telur naik maka permintaan telur ayam akan menurun dan sebaliknya, elastisitas silang harga daging ayam bernilai lebih dari 0 yaitu 0,911 artinya 
ISSN : 2622-6154 (print)

daging ayam merupakan barang substitusi (pengganti) dari telur ayam. sedangkan elastisitas silang harga beras bernilai kurang dari 0 yaitu - 0,233 artinya beras merupakan barang komplementer (pelengkap) dari telur ayam. Elastisitas pendapatan bernilai kurang dari 0 yaitu $-0,476$ artinya pendapatan merupakan barang inferior yang berarti bahwa jika pendapatan naik maka permintaan akan telur ayam berkurang.

Berdasarkan kesimpulan diatas maka saran yang dapat diberikan adalah pemerintah diharapkan selalu melakukan pengawasan dan pengamanan terhadap kebutuhan permintaan dan ketersediaan telur ayam agar selalu terpenuhi dengan baik, perlu adanya pengawasan pada kestabilan harga barang lain yang mempengaruhi permintaan telur ayam di Kabupaten Magetan dan pemerintah harus melakukan penstabilan harga ketika terjadi inflasi tinggi agar tidak terlalu berdampak buruk pada kesejahteraan masyarakat.

\section{UCAPAN TERIMAKASIH}

Terimakasih kepada Kedua Orang Tua, Dekan, Kepala Program Studi Agribisnis UNS, Dosen Pembimbing, Pihak Instansi dan teman-teman saya yang telah memberikan dukungan, bimbingan, semangat, serta doa yang tidak pernah terputus sehingga saya dapat menyelesaikan artikel ini dengan lancar. Penulis berharap semoga artikel ini bermanfaat sekaligus menambah pengetahuan bagi penulis sendiri khususnya dan pembaca pada umumnya.

\section{DAFTAR PUSTAKA}

Antriyandarti, E. 2012. Ekonomika Mikro Untuk Ilmu Pertanian. Yogyakarta: Nuha litera.

Badan Pusat Statistik. 2017. Kabupaten Magetan Dalam Angka 2017. Badan Pusat Statistik Kabupaten Magetan. Magetan

Endraswara, Suwardi. 2006. Metode, Teori, Teknik Penelitian Kebudayaan Ideologi, Epistologi, dan Aplikasi. Sleman: Penerbit Pustaka Widyatama.

Firdaus. 2008. Manajemen Agribisnis. Jakarta: Bumi Aksara

Fitrini, Andri dan A.N. Yanti. 2006. Analisis Permintaan Telur Ayam Ras di Kota Padang dan Faktor yang Mempengaruhinya. Jurnal Peternakan.11(2).

Gujarati, Damodar. 2003. Ekonometrika Dasar. Jakarta: Erlangga.

Isman, Fittresdy, Abubakar Hamzah dan Raja Masbar. 2011. Analisis Permintaan Telur Ayam di Aceh. Jurnal Ilmu Ekonomi 2(2).

Marwanti, Sri. 2002. Pola Pengeluaran Untuk Konsumsi Pangan Gizi Penduduk Indonesia (Analisis Data Susenas 1999). Jurnal Carakatani 17(2).

Prinyastanto, Mimit. 2015. Pengelolaan Sumberdaya Perikanan Melalui Kelembagaan Lokal Dalam Rangka Pemberdayaan Masyarakat Berbasis Kearifan Lokal Di Pesisir Selat Madura. Malang: PenerbitGunung Samudera.

Putong, Iskandar. 2003. Pengantar Ekonomi Mikro dan Makro. Jakarta: Penerbit Ghalia Indonesia.

Santoso. 2002. SPSS Versi 10 Mengolah Data Statistik Secara Profesional. Jakarta: PT. Elex Media Komputindo. 


\section{JOURNAL AGRIECOBIS}

ISSN : 2621-3974 (online)

Volume 01, Number 02 (2018)

ISSN : 2622-6154 (print)

Sudiyono. 2002. Pemasaran Pertanian. Malang: Universitas Muhammadiyah Malang.

Sumodiningrat, Gunawan. 2007. Pemberdayaan Sosial. Jakarta: PT. Kompas Media Nusantara

Supranto. 2001. Statistik Teori dan Aplikasi. Jakarta: Erlangga.

Susanto, Edy, Galih Adhy Raharja, Afif Muhammad. 2015. Analisis FaktorFaktor Yang Mempengaruhi Minat KonsumenTerhadap Pembelian Telur Ayam Ras Di Pasar Wilayah Kecamatan Babat Kabupaten Lamongan. Jurnal Ternak 6(1).

Sutisna. 2001. Perilaku Konsumen dan Komunikasi Pemasaran. Bandung: PT. Remaja Rosdakarya.

Wahyuningsih, Resti. 2008. Analisis Permintaan Telur Ayam di Jawa Timur. Jurnal Agritek 16(11). 